\title{
Analysis of Heavy Oils by FID-TLC (Part 4)
}

\section{A Rapid Method for Hydrocarbon Type Analysis of Heavy Oils}

\author{
Yojiro Ү Амамото \\ Research Center, Maruzen Oil Co., Ltd., \\ 1134-2, Gongendo, Satte-cho, Kitakatsushika-gun, Saitama 340-01
}

(Received April 4, 1985)

\begin{abstract}
A rapid method for hydrocarbon type analysis of heavy oils by FID-TLC with chemically bonded silica gel thin layer rods, which possess aminopropyl or cyanopropyl functional group, as the stationary phase has been investigated. The results indicated that Saturates (Sa), Monoaromatics (M-Ar), Diaromatics (D-Ar), Triaromatics (T-Ar), Polyaromatics (P-Ar), and Polar compounds (Po) could be accurately determined by three-stage development using $n$-hexane, toluene, and tetrahydrofurane. The standard deviation and the coefficient of variation in repeated measurements by FID-TLC method were as low as $1.5 \mathrm{wt} \%$ or less and $10 \%$ or less, respectively. Time required for determination of 10 samples was almost as short as 90 minutes.
\end{abstract}

\section{Introduction}

Since the sensitivity of each component is hardly different in Flame ionization detection-Thin layer chromatography (FID-TLC), it is widely used in analysis of heavy oils. ${ }^{1) \sim 8)}$ However, detailed hydrocarbon type analysis cannot be carried out by FID-TLC, since the stationary phase is limited to silica gel or alumina gel.

We have developed thin layer rods with chemically bonded silica gels. The rods proved to be effective for hydrocarbon type separation, as reported in our paper. ${ }^{9)}$

In this study, a rapid method for detailed hydrocarbon type analysis has been investigated by FID-TLC in which those rods served as the stationary phase.

\section{Experimental}

\subsection{Materials}

The following 6 samples of heavy oils were used : three atmospheric residues (AR), Arabian Light (AL), Arabian Heavy (AH), and Iranian Heavy (IH) ; and those hydrocracked products (HCRP), AL-HCRP, AH-HCRP, IH-HCRP. Soluble maltens separated from a $2 \mathrm{~g}$ of each sample dissolved in $60 \mathrm{~m} l$ of $n$-heptane as described in our paper ${ }^{5)}$ were used for analysis.

$n$-Pentacosane, $n$-dodecylbenzene, $n$-octadecylbenzene, acenaphthene, 2,6-dimethylnaphthalene, l-ethylnaphthalene, anthracene, 9,10-dimethylan- thracene, phenanthrene, and chrysene (Guaranteed or extra pure reagents obtained from Tokyo Kasei Kogyo) were used. As developing solvents for column chromatography or FID-TLC, $n$-hexane, cyclohexane, benzene, toluene, methanol, and tetrahydrofurane (guaranteed or for liquid chromatography use of Wako Pure Chemical Industries) were used.

For adsorption column chromatography, silica gel (Silica Gel 60 of Merck) activated at $250^{\circ} \mathrm{C}$ for 20 hours and alumina gel (of chromatography use of Wako) activated at $400^{\circ} \mathrm{C}$ for 20 hours were used.

\subsection{Apparatus and Methods \\ 2.2.1 FID-TLC}

Iatroscan TH-10 (Iatron Laboratories Inc.) was used for FID-TLC analysis, and Chromarod $\mathrm{NH}_{2}-$ SII and Chromarod CN-SII, both of which composed of $40 \%$ chemically bonded layer and $60 \%$ silica layer as the part of detection by FID, were used as the stationary phase as reported in our paper.9)

C-R1A type Datalyzer (Simadzu) was also used for treatment of FID data.

\subsubsection{Golumn Ghromatography}

The hydrocarbon type separation of maltens (Ma) by column chromatography was carried out using a modified method of USBM-API.10)

$1 \mathrm{~g}$ of Ma dissolved in $10 \mathrm{ml}$ of cyclohexane was introduced into a column packed with silica gel and alumina gel. The ratio of $\mathrm{Ma}$ to gel was 50 
for each gel. Saturates (Sa), Monoaromatics (MAr), Diaromatics (D-Ar), Triaromatics ( $\mathrm{T}-\mathrm{Ar}$ ), and Polyaromatics plus Polar compounds ( $\mathrm{P}-\mathrm{Ar}+$ Po) were eluted succesively by column chromatography with $700 \mathrm{ml}$ each of cyclohexane, $5 \%$ benzene-95\% cyclohexane mixture, $15 \%$ benzene$85 \%$ cyclohexane mixture, $70 \%$ benzene- $30 \%$ cyclohexane mixture, and 50\% methanol-50\% benzene mixture.

\section{Results and Discussion}

\subsection{Analytical Conditions}

Since the accuracy of analysis by FID-TLC largely depends on the analytical conditions such as developing solvent and method, weight of sample loaded in TLC and combustion condition in FID, these conditions must be thoroughly investigated for each sample.

In this study, the combustion conditions were adjusted to the optimum conditions described elsewhere, ${ }^{4)}$ and the best solvent and developing method were identified, then the weight of sample loaded was assessed.

\subsubsection{Developing Solvent and Method}

Table 1 gives $\mathrm{Rf}$ values of 10 standard samples developed with $n$-hexane.

It is suggested that $\mathrm{Sa}, \mathrm{M}-\mathrm{Ar}, \mathrm{D}-\mathrm{Ar}$, and $\mathrm{T}-\mathrm{Ar}$ can be separated by FID-TLC with Chromarod $\mathrm{NH}_{2}-\mathrm{SII}$ or Chromarod CN-SII. Chrysene as $\mathrm{P}-\mathrm{Ar}$ could not be detected, because it was not developed up to the part of detection whose $\mathrm{Rf}$ value was smaller than 0.4 . It could, however, be detected by developing with toluene for which the $\mathrm{Rf}$ value was 0.8 .

It is suggested, therefore, that a rapid and detailed hydrocarbon type separation of heavy oils can be carried out according to the three-stage development as follows. At first, by developing the sample up to $10 \mathrm{~cm}$ on the rod with $n$-hexane, $\mathrm{Sa}, \mathrm{M}-\mathrm{Ar}$, D-Ar and T-Ar are detected by FID. Then, by developing it up to $6 \mathrm{~cm}$ on the rod with THF after

Table 1 Rf Values of Various Standard Samples for Chemically Bonded Chromarods

\begin{tabular}{l|ccc}
\hline \multicolumn{1}{c|}{ Sample } & $\begin{array}{c}\text { Hydrocarbon } \\
\text { Type }\end{array}$ & $\mathrm{NH}_{\mathbf{2}}$-SII & CN-II \\
\hline n-Pentacosane & $\mathrm{Sa}$ & 0.84 & 0.85 \\
n-Dodecylbenzene & $\mathrm{M}$-Ar & 0.70 & 0.75 \\
n-Octadecylbenzene & $\mathrm{M}-\mathrm{Ar}$ & 0.71 & 0.75 \\
1-Ethylnaphthalene & $\mathrm{D}-\mathrm{Ar}$ & 0.62 & 0.61 \\
2, 6-Dimethylnaphthalene & $\mathrm{D}-\mathrm{Ar}$ & 0.58 & 0.59 \\
Acenaphthene & $\mathrm{D}-\mathrm{Ar}$ & 0.56 & 0.62 \\
Anthracene & $\mathrm{T}-\mathrm{Ar}$ & 0.47 & 0.52 \\
Phenanthrene & $\mathrm{T}-\mathrm{Ar}$ & 0.51 & 0.52 \\
9, 10-Dimethylanthracene & $\mathrm{T}-\mathrm{Ar}$ & 0.44 & 0.53 \\
Ghrysene & $\mathrm{P}-\mathrm{Ar}$ & $<0.4$ & $<0.4$ \\
\hline
\end{tabular}

developing it with toluene up to $8 \mathrm{~cm}, \mathrm{P}-\mathrm{Ar}$ and $\mathrm{Po}$ are detected by FID.

Figs. 1 and 2 show FID-TLC chromatograms of AL-AR-Ma by Chromarod $\mathrm{NH}_{2}-\mathrm{SII}$ and Chromarod CN-SII, respectively. Both figures shows that Sa, M-Ar, D-Ar, T-Ar, P-Ar, and Po were separated sharply from each other.

\subsubsection{Weight of Sample Loaded}

Since the separation conditions and accuracy of analysis vary with the weight of sample loaded in FID-TLC, the effects of weight on the sensitivity of components and repeatability of measurements were investigated.

1 st

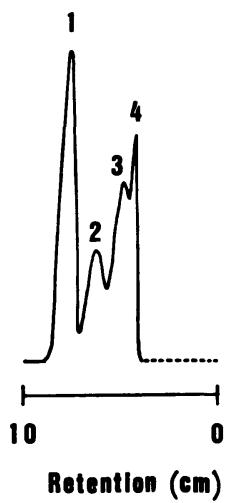

2 nd

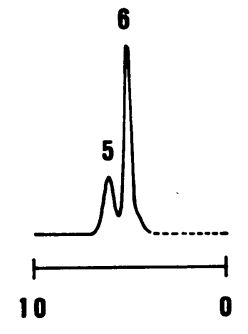

Retention (cm)

1 : Saturates (Sa)

2: Monoaromatics (M-Ar)

3: Diaromatics (D-Ar)

4: Triaromatics (T-Ar)

5 : Polyaromatics (P-Ar)

6 : Polar compounds (Po)

Fig. 1 FID-TLC Chromatograms of AL-AR-Ma by Chromarod $\mathrm{NH}_{2}-\mathrm{S}$ II

1 st

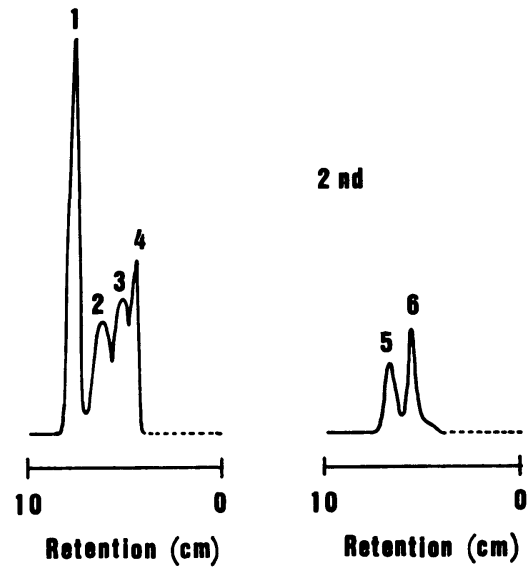

$1,2,3,4,5,6$ : Described in Fig. 1

Fig. 2 FID-TLC Chromatograms of AL-AR-Ma by Chromarod CN-S II 
Spotting $0.5 \mu l$ of a sample solution containing $5 \sim 20$ wt $\%$ of AL-AR-Ma, relations between weights of sample loaded ranging from 25 to100 $\mu \mathrm{g}$ and contents of components were examined. Mean values for 5-repeated measurements by Chromarod $\mathrm{NH}_{2}-\mathrm{SII}$ are shown in Fig. 3.

Although this figure shows that the content of every component varying with the weight of sample loaded up to $40 \mu \mathrm{g}$, the former hardly varies with the latter varying between 50 and $100 \mu \mathrm{g}$. The standard deviations of the contents of components for those repeated measurements decrease with increasing weight of sample loaded, but they become as low as $1.5 \mathrm{wt} \%$ or less between 50 and $100 \mu \mathrm{g}$ as shown in Fig. 4. The coefficient of variation becomes smaller than $10 \%$ between 50 and $100 \mu \mathrm{g}$

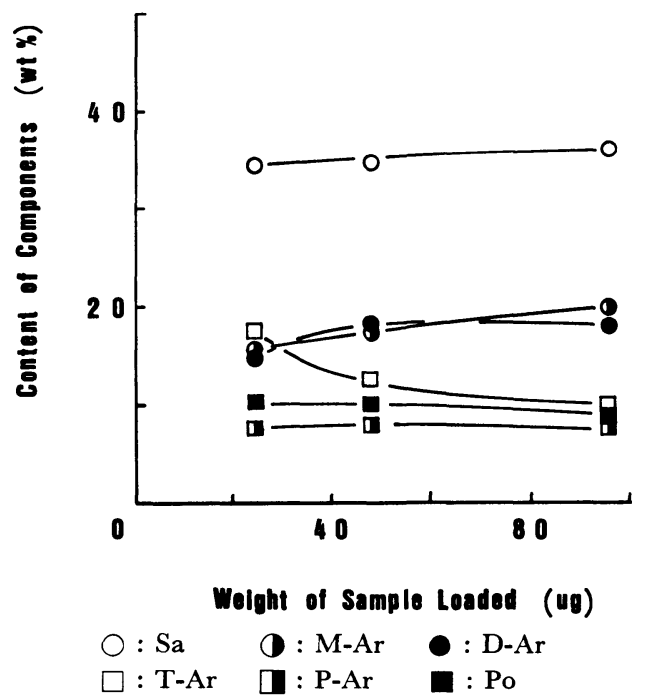

Fig. 3 Hydrocarbon Type Analysis of AL-AR-Ma for Various Weights of Sample Loaded by Chromarod $\mathrm{NH}_{2}$-S II

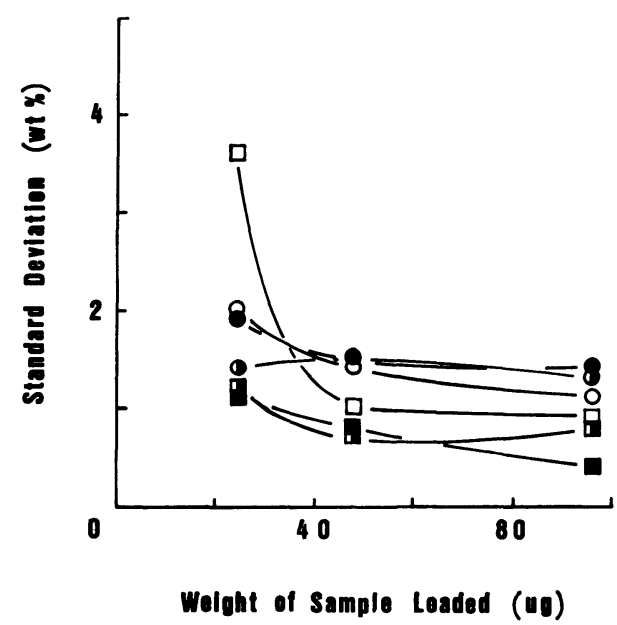

$\bigcirc, \boldsymbol{\top}, \bullet, \square, \mathbf{\square}, \mathbf{\square}$ : Described in Fig. 3

Fig. 4 Standard Deviation of Hydrocarbon Type Analysis for Various Weights of Sample Loaded

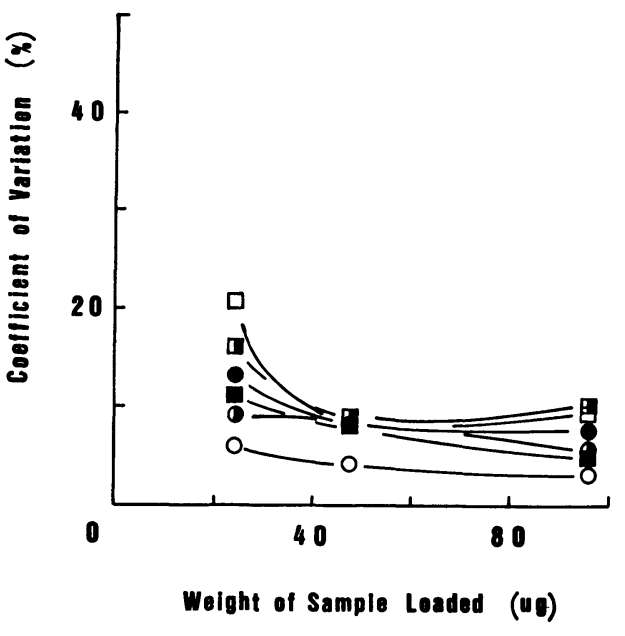

$\bigcirc, \bigcirc, \bigcirc, \square, \square, \square$ : Described in Fig. 3

Fig. 5 Coefficient of Variation of Hydrocarbon Type Analysis for Various Weights of Sample Loaded

Table 2 Repeatability of Hydrocarbon Type Analysis for Optimum Weight of Sample Loaded by Chromarod $\mathrm{NH}_{2}$-SII $(\mathrm{wt} \%)$

\begin{tabular}{c|rrrrrr}
\hline \multirow{2}{*}{ No. } & \multicolumn{7}{|c}{ Composition } \\
\cline { 2 - 7 } & Sa & M-Ar & D-Ar & T-Ar & P-Ar & Po \\
\hline \multirow{2}{*}{1} & 34.0 & 15.9 & 18.8 & 13.0 & 8.7 & 9.6 \\
2 & 33.5 & 16.2 & 18.3 & 12.4 & 8.4 & 11.2 \\
3 & 34.5 & 16.9 & 18.6 & 11.5 & 8.5 & 10.0 \\
4 & 37.0 & 16.6 & 16.3 & 13.2 & 7.9 & 9.0 \\
5 & 33.1 & 20.0 & 17.7 & 10.4 & 7.9 & 10.9 \\
6 & 34.9 & 17.4 & 18.5 & 12.6 & 7.7 & 8.9 \\
7 & 35.0 & 15.5 & 20.8 & 13.5 & 6.4 & 8.8 \\
8 & 34.2 & 17.2 & 18.4 & 12.1 & 8.2 & 9.9 \\
9 & 37.0 & 18.8 & 15.2 & 11.1 & 7.9 & 10.0 \\
10 & 32.9 & 19.0 & 18.4 & 12.7 & 7.1 & 9.9 \\
\hline $\bar{X}$ & 34.6 & 17.4 & 18.1 & 12.3 & 7.9 & 9.8 \\
SD & 1.4 & 1.5 & 1.5 & 1.0 & 0.7 & 0.8 \\
GV $(\%)$ & 4.2 & 8.5 & 8.3 & 8.0 & 8.7 & 8.1 \\
\hline
\end{tabular}

of sample loaded although the coefficient itself scatters widely in the lower range of weight of sample loaded, as shown in Fig. 5. Table 2 gives the results of the measurements repeated 10 times at $50 \mu \mathrm{g}$ of sample loaded.

It was also observed that Chromarod CN-SII had the same tendency as Chromarod $\mathrm{NH}_{2}$-SII.

\subsection{Rapid Method for Hydrocarbon Type} Aanalysis by FID-TLG

Procedures for rapid analytical method to determine the contents of Sa, M-Ar, D-Ar, T-Ar, $\mathrm{P}-\mathrm{Ar}$ and Po by FID-TLC are described below. It takes about 90 minutes to analize 10 samples.

(1) Spot $0.5 \mu l$ of the sample toluene solution adjusted to a concentration of $10 \mathrm{wt} \%$ on the rod with a $0.5 \mu l$ glass capillary for TLC.

(2) Develop the spotted sample to $10 \mathrm{~cm}$ on the rod after hanging for 5 minutes in the de- 
Table 3 Comparison of FID-TLC and Column Chromatography (wt $\%$ )

\begin{tabular}{|c|c|c|c|c|c|c|c|c|c|c|c|}
\hline \multirow{2}{*}{ Sample } & \multicolumn{6}{|c|}{ FID-TLC } & \multicolumn{5}{|c|}{ Column Chromatography } \\
\hline & $\mathrm{Sa}$ & $\mathrm{M}-\mathrm{Ar}$ & D-Ar & $\mathrm{T}-\mathrm{Ar}$ & P-Ar & Po & $\mathrm{Sa}$ & $\mathrm{M}-\mathrm{Ar}$ & D-Ar & $\mathrm{T}-\mathrm{Ar}$ & $\mathrm{P}-\mathrm{Ar}+\mathrm{Po}$ \\
\hline $\mathrm{AL}-\mathrm{AR}-\mathrm{Ma}$ & 34.6 & 17.4 & 18.1 & 12.3 & 7.9 & 9.8 & 37.0 & 16.5 & 11.3 & 12.2 & 23.0 \\
\hline $\mathrm{AH}-\mathrm{AR}-\mathrm{Ma}$ & 21.5 & 12.6 & 15.7 & 17.4 & 14.3 & 18.5 & 30.4 & 16.5 & 11.3 & 13.1 & 28.7 \\
\hline $\mathrm{IH}-\mathrm{AR}-\mathrm{Ma}$ & 32.5 & 10.7 & 15.1 & 11.7 & 11.6 & 18.3 & 38.0 & 14.8 & 9.3 & 10.2 & 27.7 \\
\hline AL-HCRP-Ma & 57.4 & 17.7 & 15.8 & 2.6 & 3.5 & 3.1 & 57.8 & 18.3 & 10.8 & 5.3 & 7.8 \\
\hline AH-HCRP-Ma & 47.3 & 18.4 & 18.1 & 3.2 & 6.7 & 6.4 & 56.4 & 16.3 & 8.2 & 7.3 & 11.8 \\
\hline IH-HCRP-Ma & 55.7 & 16.8 & 13.8 & 2.8 & 4.4 & 6.5 & 58.7 & 15.0 & 10.5 & 4.4 & 11.4 \\
\hline
\end{tabular}

veloping tank containing $n$-hexane.

(3) Dry the rod at room temperature and then measure the peak areas of Sa, M-Ar, D-Ar and $\mathrm{T}-\mathrm{Ar}$ in the FID chromatogram for silica gel thin layer.

(4) Develop it up to $8 \mathrm{~cm}$ on the rod after hanging for 5 minutes in the developing tank containing toluene.

(5) Dry the rod at room temperature.

(6) Develop it up to $6 \mathrm{~cm}$ on the rod after hanging for 5 minutes in the developing tank containing THF.

(7) Dry the rod at room temperature and then measure the peak areas of $\mathrm{P}-\mathrm{Ar}$ and $\mathrm{Po}$ in the FID chromatogram for silica gel thin layer.

(8) Calculate the contents of components from peak areas of those measured in (3) and (7).

\subsection{Gomparison with the Conventional Meth-} od

Table 3 shows a comparison of the analytical results of three ARs and respective HCRPs by FID-TLC with those by silica-alumina dual column chromatography.

Table 3 reveals that the analytical results by FID-TLC are not the same as those by the dual column chromatography. These discrepancies are caused by different separation mechanisms in which different elution solvents or gels were used. It cannot be stated unequivocally which method is to be preferred, but the components are generally not so clearly separated from each other by adsorption column chromatography due to the overlapping of $\mathrm{Sa}$ and Aromatics (Ar) with each other. Analytical values of Sa by FID-TLG are smaller than those by conventional method as shown in Table 3. This indicates that $\mathrm{Sa}$ and $\mathrm{Ar}$ are more clearly separated from each other by FID-TLC. It, therefore, suggests that FID-TLC would be more satisfactory than the conventional method for hydrocarbon type analysis of heavy oils.

Fig. 6 shows FID-TLC chromatograms of each component separated from AH-AR-Ma by dual column chromatography. Individual components
Sa

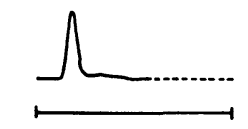

m-Ar

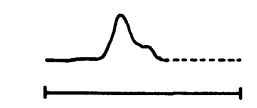

D-Ar

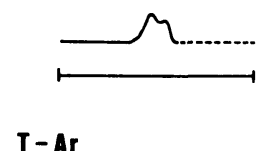

$\mathbf{T}-\mathbf{A r}$

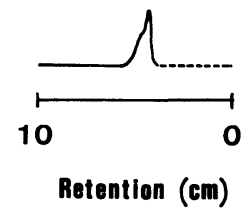

Fig. 6 FID-TLC Chromatograms of Components Separated from AH-AR-Ma by Column Chromatography

do not show any single peak in FID-TLC.

This also suggests that FID-TLC would be more suitable for hydrocarbon type analysis of heavy oils.

\section{Conclusions}

A rapid method for detailed hydrocarbon type analysis was investigated by FID-TLC with Chromarod $\mathrm{NH}_{2}-\mathrm{SII}$ and Chromarod CN-SII (thin layer rods with aminopropyl and cyanopropyl bonded silica gels, respectively) serving as the stationary phase.

The type analysis of heavy oils separating into Sa, M-Ar, D-Ar, T-Ar, P-Ar and Po could be performed adequately by three-stage development using n-hexane, toluene, and tetrahydrofuran.

The results of standard deviation and coefficient of variation in repeated measurements by this method were as low as $1.5 \mathrm{wt} \%$ or less and $10 \%$ or less, respectively. Time required for determination of 10 samples was almost as short as 90 minutes. 


\section{References}

1) Poirier, M. A., George, A. E., ACS, Div. Petrol. Chem., Prep., 27, 973 (1982).

2) Selucky, M. L., Anal. Chem., 55, 141 (1983).

3) Poirier, M. A., George, A. E., J. Chromatogr. Sci., 21, 331 (1983).

4) Yamamoto, Y., Kawanobe, T., Sekiyu Gakkaishi, 27, (3), 269 (1984).

5) Yamamoto, Y., Kawanobe, T., Sekiyu Gakkaishi, 27, (5), 373 (1984).
6) Sawada, S., Takahashi, T., Saito, K., Matsumura, T., Nenryo Kyokaishi, 63, 128 (1984).

7) Poirier, M. A., Rahimi, R., Ahmed, S. M., J. Chromatogr. Sci., 22, 116 (1984).

8) Nakata, S., Morikawa, Y., Takahashi, H., Shiroto, Y., Sekiyu Gakkaishi, 28, (1), 38 (1985).

9) Yamamoto, Y., Ohno, Y., Sekiyu Gakkaishi, 28, (6), 493 (1985).

10) Hirsch, D. E., Hopkins, R. L., Goleman, H. J., Cotton, F. O., Thompson, C. J., Anal. Chem., 44, (6), 915 (1972).

要

FID-TLG による重質油の分析（第 4 報）重質油の迅速炭化水素タイプ分析法

山本 洋 次 郎

丸善石油(株)研究所, 340-01 埼玉県北葛飾郡幸手町権現堂 1134-2

アミノプロピル基あるいはシアノプロピル基を有する化学結 合型シリカゲル薄層棒（クロマロッド $\mathrm{NH}_{\mathbf{2}}-\mathrm{S} I I$ および同 $\mathrm{CN}-$ SII）を固定相として用い，FID-TLG による重質油の詳細な 迅速炭化水素タイプ分析法を検討した。

その結果, 以下の 3 回展開によれば重質油中のマルテン分 (Ma) を飽和分 $(\mathrm{Sa})$, 単環芳香族分 $(\mathrm{M}-\mathrm{Ar}), 2$ 環芳香族分 $(\mathrm{D}-\mathrm{Ar}) ， 3$ 環芳香族分 ( T-Ar)，多環芳香族分 (P-Ar)，お よび極性物質 $(\mathrm{Po})$ の 6 成分に精度良く分離定量できることが わかった。すなわち, まず $n$-ヘキサンで 1 回目展開を $10 \mathrm{~cm}$ まで行い，展開された Sa，M-Ar，D-Ar，扰よび T-Arを FID で検出する。その後, トルェンで 2 回目展開を $8 \mathrm{~cm}$ ま で行い, P-Ar を展開した後, 引き続いて 3 回目展開を $\mathrm{THF}$ で $6 \mathrm{~cm}$ まで行い残分の Po を展開し, FID で P-Ar とPo を検出する。Figs. 1，2 にクロマロッド $\mathrm{NH}_{2}-\mathrm{S} I I$ および同
GN-SII を用いて，AL-AR-Ma を分離した結果を示した。 いずれにおいても Sa, M-Ar, D-Ar, T-Ar, P-Ar, および Po の 6 成分は明りょらに分離されていることがわかる。

クロマロッド $\mathrm{NH}_{2}-\mathrm{S} I I$ を用いた場合について, 試料負荷量 25 100 $\mu \mathrm{g}$ の範囲での 各成分の含有率の変化を調べた結果を Fig. 3 に示した。試料負荷量が少ないと, Sa, M-Ar, D-Ar および T-Ar の組成は試料負荷量の違いによって大きく異な る傾向が認められるが，50〜100 $\mu \mathrm{g}$ ではほとんど変化がない ことがわかった。繰り返し精度についても，Figs. 4,5 に示し たように繰り返し測定時の標準偏差, 变動係数ともに試料負荷 量が少ないと大きくなる傾向が認められるが，50〜100 $\mu \mathrm{g}$ では 標準偏差 $1.5 \mathrm{wt} \%$ 以下と小さく，変動係数も10\% 以下と良 好であることがわかった。

分析所要時間も 10 試料の分析で約 90 分と短くて良い。

\section{Keywords}

Chemically bonded silica, Flame ionization detection, Heavy oil, Hydrocarbon type analysis, Thin layer chromatography 